\title{
Investor relations on the internet: a survey in the Euronext zone
}

Citation for published version (APA):

Geerings, J., Bollen, L. H. H., \& Hassink, H. F. D. (2002). Investor relations on the internet: a survey in the Euronext zone. METEOR, Maastricht University School of Business and Economics. METEOR Research Memorandum No. 08 https://doi.org/10.26481/umamet.2002008

Document status and date:

Published: 01/01/2002

DOI:

10.26481/umamet.2002008

Document Version:

Publisher's PDF, also known as Version of record

\section{Please check the document version of this publication:}

- A submitted manuscript is the version of the article upon submission and before peer-review. There can be important differences between the submitted version and the official published version of record.

People interested in the research are advised to contact the author for the final version of the publication, or visit the DOI to the publisher's website.

- The final author version and the galley proof are versions of the publication after peer review.

- The final published version features the final layout of the paper including the volume, issue and page numbers.

Link to publication

\footnotetext{
General rights rights.

- You may freely distribute the URL identifying the publication in the public portal. please follow below link for the End User Agreement:

www.umlib.nl/taverne-license

Take down policy

If you believe that this document breaches copyright please contact us at:

repository@maastrichtuniversity.nl

providing details and we will investigate your claim.
}

Copyright and moral rights for the publications made accessible in the public portal are retained by the authors and/or other copyright owners and it is a condition of accessing publications that users recognise and abide by the legal requirements associated with these

- Users may download and print one copy of any publication from the public portal for the purpose of private study or research.

- You may not further distribute the material or use it for any profit-making activity or commercial gain

If the publication is distributed under the terms of Article $25 \mathrm{fa}$ of the Dutch Copyright Act, indicated by the "Taverne" license above, 


\title{
Investor Relations on the Internet:
}

\author{
A survey of the Euronext zone
}

Jorn Geerlings*, Laury Bollen**, Harold Hassink***

\section{Maastricht Accounting and Information Management Research and Education Center University Maastricht}

\section{June 2002}

* Doctoral student, Faculty of Economics and Business Administration, University Maastricht ** Associate Professor of Information Management, Faculty of Economics and Business Administration, University Maastricht *** Professor of Auditing, Faculty of Economics and Business Administration, University Maastricht 


\title{
Investor Relations on the Internet:
}

\section{A survey of the Euronext zone}

Key words: Investor Relations, Internet, Euronext, Belgium, France, the Netherlands

\begin{abstract}
This study investigates the investor relations activities on the Internet of companies listed on the Euronext stock exchange. For this purpose, the homepages of the 50 largest listed companies in each of the countries Belgium, France and the Netherlands were searched and screened for investor relations items. Results obtained by using a three stages model show that most companies in the Euronext zone are in the second stage of Internet investor relations. In this stage, information available through other sources is combined to better inform investors. In the third stage companies use the full interactive possibilities of the Internet for investor relations purposes. French and Dutch companies use the Internet for investor relations purposes more widely and more intensely than do Belgian companies. The study also revealed a size effect; large companies use the Internet for investor relations purposes more extensively than do smaller companies. This conclusion holds for each of the three countries. The leading companies in France and the Netherlands are either in the third stage of Internet investor relations or they are ready to enter it.
\end{abstract}

\section{INTRODUCTION}

In the last few years the Internet has become increasingly important to companies - not only for marketing purposes, where the Internet is an important medium used to promote company products, but also for financial purposes. The role of the Internet in investor relations is an example of its use for financial purposes.

This study investigates the use of the Internet for investor relations purposes by companies listed on the pan-European stock exchange Euronext. Euronext was founded in September 
2000 by a merger of the stock exchanges of Brussels (Brussels Exchanges or BXS), Paris (ParisBourse) and Amsterdam (Amsterdam Exchanges or AEX). The purpose of the merger was to create scale, to enhance liquidity, transparency and price discovery resulting from the creation of a single order book and to realize cost savings, especially from investments in information technology. Euronext has indicated that it is open to new partners and that it intends to merge with or acquire other European stock exchanges. As a matter of fact, the Portuguese stock market BVLP joined Euronext at the beginning of 2002 and the stock exchange of Luxembourg has already intensified cooperation, with the intent to join Euronext in the future. Based on market capitalization, Euronext is the second European stock exchange; it is smaller than the Deutsche Börse, but larger than the London Stock Exchange. ${ }^{1}$ Figure 1 summarizes some key data of these three stock exchanges.

$<$ insert Figure 1 about here $>$

The decision of the Portuguese stock market to join Euronext was taken after the period that the screening of the homepages for the current study was performed (November-December 2001). Therefore, Internet investor relations of Portuguese companies were not investigated in the current study.

The aim of this study is fourfold. The first aim is to present a research overview of empirical work focusing on investor relations activities on the Internet. Most previous studies provide some partial analysis of Internet use for investor relations purposes. This study aims to present a more comprehensive analysis. The second aim is to provide a more sophisticated model that can be used to determine companies' use of the Internet for investor relations purposes. The

1. For more on Euronext, see the homepage www.euronext.com 
third aim is to present evidence of investor relations activities on the Internet in the three Euronext countries, using the model mentioned before. At this moment, evidence is either non-existent (Belgium) or rather limited (France and the Netherlands, see Lymer et al., 1999). Finally, the fourth aim is to compare the results with previous empirical work to determine the position of companies in the Euronext zone in comparison with companies elsewhere.

This study is organized as follows. Section 2 introduces the concept of investor relations via the Internet. An overview of previous research on Internet investor relations is provided in Section 3. Section 4 outlines the sample, research instrument and research method of this study. The empirical results are presented in Section 5. Finally, the conclusions are provided in Section 6.

\section{INVESTOR RELATIONS AND THE INTERNET}

Since companies compete with each other for capital, they need good communications with investors to be regarded as a relevant investment opportunity. Marston (1996) defines investor relations as 'the link between a company and the financial community, providing information to help the financial community and the investing public evaluate a company'. Companies use a multi-channel approach to inform investors. Information is traditionally communicated by means of financial reports, press releases, road shows and in analyst meetings. The Internet is a relatively new communication channel for investor relations. The Internet can be used as medium to provide investors with a copy of the traditional paper-based annual report, but it also offers new opportunities to present and communicate information. These include technology-specific presentation advantages, the use of cookie technology, and direct forms of communication like mailing lists and online participation (Deller et al., 1999). The advantages of providing information to investors on the Internet are speed, lower costs, and 
the possibility of reaching large groups of investors. Hedlin (1999) describes three stages of investor relations on the Internet. The first stage is the Internet presence, offering general company information. The second stage, which is more interesting for investors, is using the Internet to communicate investor information. Finally, in the third stage, a company can

exploit the Internet for the specific advantages it offers. In this study, based on the ideas of Hedlin (1999) the following three stages are defined:

Stage I: 1. Annual and interim reports on the Internet. In this stage, companies provide their current corporate annual report (including the balance sheet, profit \& loss account, notes, cash flow statement), reports of previous years, interim reports and environmental and/or social reports in an electronic format. Here, the Internet is used as a medium to provide information that is already available through other sources. Although the information provided is likely to be relevant to investors, mostly the information provided and the structure in which the information is presented are not specifically aimed at investors.

Stage II: 2. Press releases and further information services on the Internet. In this stage, companies provide press releases, a financial calendar, the share price, the organizational structure and external links. In terms of content and structure the information is specifically aimed at investors and the Internet is used as a medium to combine information available through other sources, so that investors may be better informed.

Stage III: In the third stage of Internet investor relations, companies use distinctive features of the Internet that enable them to contact or inform investors in ways that were hardly possible using traditional communication channels. The specific investor relations features may take various forms: 
3. The use of presentation advantages of the Internet. These include the possibility of providing hyperlinks and internal search engines, the use of cookies, and the presentation of data in time series or different formats so that the information provided may be processed further. Also, the homepages may be multilingual.

4. Direct contact via e-mail and mailing lists. Here, companies provide e-mail access to the investor relations department, regularly updated information to mailing list subscribers, answers to frequently asked questions, and an online investor information order service.

\section{Video or audio recordings of meetings and online participation in meetings.}

Here, companies allow investors to view presentations by company executives, to listen to audio recordings of presentations and to participate in online meetings.

Below, the findings of previous research are summarized using the five categories mentioned above. In Section 5 the same categories are used to present evidence on companies in the Euronext zone.

\section{PREVIOUS RESEARCH}

The data gathering of previous studies took place in the time frame 1995-1999. Appendix A at the end of the study provides a more extensive and chronological overview of the studies discussed below. In some studies (Deller et al., 1999, Gowthorpe and Amat, 1999 and Brennan and Kelly, 2000), the results are based on the number of companies in the sample that actually engage in Internet investor relations activities, while in other studies the total number of companies in the sample are used as a base of reference. For reasons of comparison, in this study all percentages presented are based on the total number of 
companies in the sample. To do this some percentages presented in the original studies had to be recalculated.

\section{Stage I: 1. Annual and interim reports on the Internet}

The presentation of corporate annual reports and interim reports on the homepages typically represents the first stage of Internet investor relations. In this stage, the focus is on the disclosure of full annual reports, on interim reports and on stand-alone financial information that has already been published on paper. US companies were amongst the first to engage in this form of Internet investor relations. In 1995-1996, 31\% of US listed companies offered their full financial report on the Internet (Petravick and Gillett, 1996). In 1998, 45\% of US companies provided their full annual report on their homepages, and $54 \%$ provided quarterly reports (Ettredge et al., 2001). Also in 1998, 33\% of UK companies provided their full annual report and 20\% provided their report in part (Craven and Marston, 1999). In the same year, $46 \%$ of the German companies presented their balance sheets and $15 \%$ presented financial statement data time series (Deller et al., 1999). A study by Lymer et al. (1999) indicated that in 1999, German and UK companies still used the Internet less extensively in comparison with US companies, as far as presenting their balance sheet, profit \& loss account, cash flow statement and notes to their financial statements were concerned. In 1998, 9\% of Spanish companies provided some financial information on the Internet, with $4 \%$ offering their full annual report, and 3\% interim reports (Gowthorpe and Amat, 1999). For Sweden, in 1999, $83 \%$ of companies presented some financial information, and a 'majority' of the companies disclosed the full annual report (Hedlin, 1999). In Ireland, in the same year, 38\% of companies provided the full annual report (Brennan and Kelly, 1999). Also in 1999, Lymer et al. (1999) investigated financial reporting on the Internet with respect to 22 countries. The proportion presenting their balance sheet ranged from $7 \%$ in Malaysia to $77 \%$ in Canada. Profit \& loss accounts were found in $10 \%$ of the sample (Malaysia) to $83 \%$ (Canada); cash 
flow statements in $3 \%$ of the sample (Singapore) to $73 \%$ (Canada) and notes to the accounts in $0 \%$ (Singapore and Chile) to $57 \%$ of the sample (US).

\section{Stage II: 2. Press releases and further information services on the Internet}

The use of the Internet for the provision of specific information for investors that is available through other sources represents the second stage of the model. Most companies in the US (80\%), UK (65\%), Germany (61\%) (Deller et al., 1999) and Sweden (82\%) (Hedlin, 1999) offered press releases on their homepages in 1998. In a later study similar results were found for the US (80\%) (Ettredge et al., 2001). Irish companies provide press releases on the Internet to a lesser extent (45\%) (Brennan and Kelly, 2000). Financial calendars were more often found in Germany (28\%) than in the UK (13\%), Ireland (12\%) and the US (8\%) (Deller et al., 1999, Brennan and Kelly, 2000). The score for the US is confirmed in a second study (12\%) (Ettredge et al., 2001). On the other hand, US companies offered the current share price more often on their homepages (70\%) than did UK (21\%) and German (32\%) companies (Deller et al., 1999). Sweden again had a median position as nearly half of the Swedish companies (48\%) had placed their current share prices on their homepages (Hedlin, 1999), followed by Ireland, where $21 \%$ of the companies provided this information (Brennan and Kelly, 2000). In contrast, in Spain, only one company in a sample of 379 companies reported its current share price (Gowthorpe and Amat, 1999). Note that in another study, the US scored significantly lower as far as providing the current share price was concerned (15\%) (Ettredge et al., 2001). However, in the latter study, the companies were smaller than those in the Deller et al. study (1999), and this may explain the differences observed.

\section{Stage III: 3. Presentation advantages of the Internet}

The third stage of the model refers to the use of specific advantages offered by the Internet. One area of potential advantage is the way information can be approached and presented on 
the Internet. This includes the use of hyperlinks, the use of specific file formats ${ }^{2}$, internal search engines, cookie technology ${ }^{3}$, the possibility of changing the language in which the information is offered, and the possibility of downloading files. In 1999, more UK companies (27\%) used hyperlinks than did US (6\%) and German companies (9\%) (Deller et al., 1999). Swedish companies again held a median position, with $12 \%$ using hyperlinks on their homepages (Hedlin, 1999). Furthermore, corporate reports in PDF-format were more often found in the US (32\%) and the UK (25\%) than in Germany (12\%) (Deller et al., 1999). Financial data in an interactive format was relatively scarce in all of the countries (US: 12\%; UK: 4\%; Germany: 5\%) (Deller et al., 1999). Internal search engines were more often found in the US (65\%) than in the UK (24\%) and Germany (30\%) (Deller et al., 1999). The same was true for cookies (US: 24\%; UK: 9\%; Germany: 4\%) (Deller et al., 1999). In Spain, 28 companies (7\%) offered their homepages in Spanish as well as in English (Gowthorpe and Amat, 1999), while in Sweden 80\% presented their homepages in English and Swedish (Hedlin, 1999). Finally, 12\% of the Swedish companies offered the opportunity to download files (Hedlin, 1999).

\section{Stage III: 4. Direct contact via e-mail and mailing lists}

Another advantage of the Internet is the possibility of making direct contact with individual investors or groups of investors through e-mail or mailing list facilities. E-mails to the investor relations departments could be sent more often in the US $(31 \%)$ than in the UK (29\%) and Germany (22\%) (Deller et al., 1999), with Ireland following (19\%) (Brennan and Kelly, 2000). The possibility for being added to a mailing list was a scarce feature (US: 11\%; UK: 4\%; Germany: 8\%) (Deller et al., 1999). Frequently asked questions were found more often in the US (28\%) than in the UK (6\%), Germany (5\%) (Deller et al., 1999) and Ireland

2. For a discussion of different formats of presenting financial information, see Lymer et al.(1999).

3. For an explanation of this technology, see Deller et al. (1999). 
(3\%) (Brennan and Kelly, 2000). Finally, German companies (33\%) more often had an online investor information order service than did US (15\%) and UK companies (16\%) (Deller et al., 1999), with Irish companies in between (19\%) (Brennan and Kelly, 2000).

\section{Stage III: 5. Video or audio recordings of meetings and online participation in meetings}

A final advantage of the Internet is the option to engage in interactive activities with investors, for example by facilitating online sessions. In the US, UK and Germany 'only a few' companies offered presentations of meetings while no indication of online participating was found (Deller et al., 1999). Only a few Irish companies offered videos (5\%) and other presentation materials (6\%) (Brennan and Kelly, 2000). In the US, 9\% of the companies offered speeches of company executives (Ettredge et al., 2001). Overall, presentations of meetings (video or other material) were rarely found.

\section{Final observations and conclusions from previous research}

A number of previous studies showed a size effect, suggesting that large companies use the Internet more intensively for investor relations purposes than do smaller companies. In the UK there was a significant positive relationship between the size of a company and the extent of financial disclosure on the Internet (Craven and Marston, 1999). In Austria, there was a positive relationship between the quality of the homepage on the one hand, and the size of the company and the percentage of free float of the shares of the company on the other (Pirchegger and Wagenhofer, 1999). There was some tentative evidence for an industry effect. In Spain, certain industry sectors were more likely to have a homepage than were other sectors (Gowthorpe and Amat, 1999). ${ }^{4}$ In the UK, however, no significant relationship was found between industry type and extent of financial disclosure on the homepage (Craven and Marston, 1999).

4. Note that in the study by Gowthorpe and Amat (1999), there were only a few observations in some industry sectors. 
Previous studies provide a mixed picture. However, some general conclusions can be drawn:

- The advantages that the Internet offers over traditional paper-based reports are only partly used.

- English-speaking countries (the US, UK, Ireland) seem to outperform most continental European Countries (Austria, Germany, Spain) on many dimensions of using the Internet for investor relations purposes.

- There are indications of a size effect. Larger companies seem to use the Internet for investor relations purposes more often and they tend to have higher quality homepages.

- $\quad$ There is some tentative evidence for the existence of an industry effect.

- Only a few companies have entered the third stage of Internet investor relations. In countries like the US, UK and in some Western European and Scandinavian countries, a considerable percentage of companies have moved into the second stage. With respect to the first stage, the head start that US companies had in the mid-nineties has gradually disappeared, and many companies across countries have started initiatives in Internet investor relations. Nevertheless, even with respect to the first stage of Internet investor relations, sizeable differences across countries continue to exist.

\section{SAMPLE, RESEARCH INSTRUMENT AND METHOD}

\subsection{Sample}

The focus of the empirical part of this study is on investor relations activities on the Internet by the 50 largest listed companies in each of the countries Belgium, France and the Netherlands. For Belgium, the Bel20 (20 companies) and the 30 next largest companies, based on market capitalization, were taken. For France, the CAC40 (40 companies) was expanded with the 10 next largest companies, also based on market capitalization. For the Netherlands, 
the AEX-companies (25 companies) and the Midkap-companies (25 companies) were selected. The actual screening of the homepages of the companies in the sample took place in the second half of November and the first half of December 2001. Appendix B at the end of the study provides the names and market capitalization of the companies involved. ${ }^{5}$

\subsection{Research Instrument}

The research instrument of this study is based on the one used by Deller et al. (1999). The instrument of Deller et al. (1999) was extended with the following items: environmental and/or social reports, corporate reports of previous years, corporate reports in XBRL-format, the use of multilingual possibilities, the presentation of the organizational structure, external links, the last update within 24 hours and presentations by company executives. The instrument matches the three stages of Internet investor relations and consists of five main categories, each covering a number of additional items (see also the discussion in Section 2). The modified version was tested in a pilot-study focusing on the homepages of five companies in each of the three countries. Consequently, some minor final modifications were made. ${ }^{6}$ The instrument can be found in Appendix $\mathrm{C}$ at the end of this study.

\subsection{Research Method}

A content analysis was used to study the homepages in the sample for their investor relations dimensions (Weber, 1985). The first author served as the first coder. Codings that appeared problematic were discussed for consensus by the three authors prior to assigning a code. The first step was to look for the homepages of the companies selected. In most cases, the homepage could be found by means of a link on the site of Euronext; this was available for almost all of the companies in the sample (97\%). In cases where this link was not available,

5. These figures were taken from the site of Euronext and refer to the situation at the end of August 2001.

6. One of the modifications was the exclusion of the item corporate reports in 20-F format. 
several search engines on the Internet were used to find the company homepages. ${ }^{7}$ The results are presented in Section 5.

\section{EMPIRICAL FINDINGS}

\subsection{Presentation of results}

Almost all the companies in the sample had a homepage. In both Belgium and France, one company did not. For another Belgium company there was an indication that there was a homepage, although this site could not be accessed during the research period. It was therefore assumed that this company did not have a homepage.

As mentioned before, for reasons of comparison, all percentages presented are based on the total number of companies in the sample.

The results show a high use of the Internet as a medium for investor relations. In France (94\%) and the Netherlands (92\%), more companies used the Internet for investor relations purposes than in Belgium (70\%).

After the identification of the homepages, the next step was to investigate the contents using the three stage model.

\section{Stage I: 1. Annual and interim reports on the Internet}

The first step was to investigate the nature of investor relations information provided on the homepage. The results are shown in Figure 2. Note that all the percentages are taken in relation to the sample per country $(\mathrm{N}=50)$. Balance sheets, profit $\&$ loss accounts, notes and

7. These include Altavista, Corporateinformation, Infoseek, Metacrawler, Lycos and Yahoo. 
interim reports were provided very often (Belgium: 86-92\%; France: 92-96\%; the Netherlands: 96-98\%). Cash flow statements were reported more often in France and the Netherlands than in Belgium (Belgium: 58\%; France: 78\%; the Netherlands: $96 \%$ ). Up to a quarter of the companies had placed an environmental and/or social report on the Internet (Belgium: 12\%; France: 22\%; the Netherlands: 24\%). One possible explanation for these results is that this kind of reporting is relatively new in comparison with traditional financial reporting. There was a substantial difference in disclosure of corporate reports from previous years between French and Belgian companies, with Dutch companies in between (Belgium: 38\%; France: $66 \%$; the Netherlands: $52 \%$ ). On the other hand, only a few French companies provided financial data time series on their homepages, whereas in Belgium and in the Netherlands these appeared more often (Belgium: 24\%; France: 10\%; the Netherlands: 28\%). Finally, as can be seen in Figure 3, selective accounting data (e.g. stand alone sales and net income figures) were presented by nearly all companies (Belgium: 92\%; France: 94\%; the Netherlands: $100 \%)$.

$<$ insert Figure 2 about here $>$

\section{Stage II: 2. Press releases and further information services}

Almost all companies provided press releases on their homepages (Belgium: 92\%; France: 96\%; the Netherlands: 100\%). A financial calendar was also a common feature on the homepages (Belgium: 64\%; France: 62\%; the Netherlands: 76\%), although it was found less often than press releases. French companies placed their current share price on their homepages more often than did companies in Belgium or the Netherlands. (Belgium: 66\%; France: $90 \%$; the Netherlands: 70\%). Opposite results were found for information on organizational structure (Belgium: 42\%; France: 26\%; the Netherlands: 42\%). External links 
to other homepages were found on most homepages (Belgium: 82\%; France: $86 \%$; the Netherlands: 88\%). Finally, Belgian homepages were less often updated within 24 hours than were French and Dutch homepages (Belgium: 18\%; France: 36\%; the Netherlands: 46\%). The results are summarized in Figure 3.

$<$ insert Figure 3 about here $>$

\section{Stage III: 3. Presentation advantages of the Internet}

One advantage of the Internet is the use of hyperlinks to structure the navigation within the financial information provided to investors. As can be seen in Figure 4, such hyperlinked structures were rarely found (Belgium: 4\%; France: 0\%; the Netherlands: $6 \%$ ). Another option is that reports can be offered in different formats, each with specific advantages. The PDF-format is the most common form of presenting a report on the Internet, and most of the companies presented their information this way (Belgium: 88\%; France: $94 \%$; the Netherlands: 94\%). Data in processable format and data in XBRL-format are more user friendly. The first format was found only occasionally (France: 20\%; Belgium: 8\%; the Netherlands: $14 \%$ ) and the second format was not found at all. ${ }^{8}$ Presenting the homepage in more than one language is also user friendly. Multilingual homepages were found most often in France, followed by Belgium and the Netherlands (Belgium: 54\%; France: 78\%; the Netherlands: 44\%). The relative low percentage in the Netherlands is because many Dutch companies had placed their information on the Internet in English rather than in Dutch. Most French companies, on the other hand, had placed their information in French and in English. Internal search engines were most often found on French and Dutch homepages and to a lesser extent on Belgian homepages (Belgium: 48\%; France: 66\%; the Netherlands: 64\%).

8. For examples of sites containing XBRL-techniques, see www.xbrl.org 
Finally, cookie technology was used to more or less the same extent (Belgium: 30\%; France: $34 \%$; the Netherlands $34 \%$ ).

$<$ insert Figure 4 about here $>$

\section{Stage III: 4. Direct contact via e-mail and mailing lists}

This section is concerned with the extent to which investors can actually communicate with companies via the Internet. As shown in Figure 5, most of the homepages had an option to send an e-mail to the investor relations department (Belgium: 62\%; France: 88\%; the Netherlands: $82 \%$ ). The use of a mailing list (Belgium: 42\%; France: $68 \%$; the Netherlands: 62\%) and frequently asked questions (Belgium: 20\%; France: 40\%; the Netherlands: 46\%) showed basically the same pattern. Finally, online investor information order services were more often found in the Netherlands than in Belgium and France (Belgium: 42\%; France: $38 \%$; the Netherlands: $62 \%$ ).

\section{Stage III: 5. Online participation in meetings and video or audio recordings of meetings}

Apparently, as shown in Figure 5, companies were not ready yet for online participation in meetings. None of the companies in France and Belgium offered this way of communicating, while in the Netherlands $8 \%$ of the companies did. Furthermore, about the half of the French and Dutch companies placed video or audio recordings of meetings on the Internet, compared with only a small proportion of the Belgian companies (Belgium: 12\%; France: $48 \%$; the Netherlands: 54\%). Presentations by company executives show the same pattern. Nearly all companies in France and many in the Netherlands placed these presentations on the Internet while in Belgium about half of the companies did (Belgium: 46\%; France: $94 \%$; the Netherlands: 88\%). 


\section{$<$ insert Figure 5 about here $>$}

\subsection{Size and industry effect}

The research overview in Section 3 pointed at the existence of a size effect for the UK and Austria. The size effect was also studied for the Euronext companies. The 15 largest and 15 smallest companies (based on market capitalization) were taken from each country. This resulted in two subsamples: 45 large and 45 small companies. The large companies scored higher on almost all items in comparison with the smaller companies. ${ }^{9}$ The most interesting differences are presented in Figure 6. Large companies more often provide environmental and/or social reports on their homepages in comparison with smaller companies (36\% vs. $4 \%)$. The same is true for corporate reports of previous years ( $80 \%$ vs. $38 \%)$. There were also large differences for the items financial data in processable format (22\% vs. $9 \%)$ and internal search engines (71\% vs. $49 \%)$. Information on the organizational structure (51\% vs. $22 \%$ ) and the last update within 24 hours (49\% vs. 13\%) showed similar differences. In addition, video or audio recordings of meetings (56\% vs. $27 \%$ ) and presentations by company executives (93\% vs. 56\%) were found more often on the homepages of large companies. A possible explanation for these differences is that large companies have more resources and more news and therefore more reason to update their homepages. The existence of an industry effect was also investigated. However, no such effect was found. ${ }^{10}$

$<$ insert Figure 6 about here $>$

\section{CONCLUSIONS}

9. Except for the criteria online investor information order service (large companies: $40 \%$; small companies: $44 \%$ ). 
This study investigated the extent to which the Internet is used as a medium for investor relations in the Euronext zone. The evidence is presented using a three stages model in which five categories of items are identified. Corporate annual reports and interim reports were found on the homepages in all three countries. There was an increase compared to the results of previous research (Lymer et al., 1999). Press releases were found on the homepages of almost all companies in the three countries, which was also the case in previous studies that focused on other countries (e.g. Deller et al., 1999 and Hedlin, 1999). French and Dutch companies showed better results regarding direct contact via e-mail and mailing lists than did Belgian companies. This form of communication is significantly better developed in comparison with previous research (Deller et al., 1999 and Brennan and Kelly, 2000). Online participation in meetings was still a rarity. In comparison with previous research (Brennan and Kelly, 2000 and Deller et al., 1999), presentations of meetings were found relatively more often. Generally, Belgian companies use the Internet for investor relations purposes to a lesser extent than do French and Dutch companies. Also a size effect was found. Large companies in the Euronext zone used the Internet more extensively for investor relations purposes than did smaller companies. This also partially explains the Belgian results, because on average Belgian companies are smaller than French and Dutch companies (see Appendix B). Eliminating the size effect by comparing companies of equal size, the results show that differences between Belgian and Dutch companies continue to exist, though they become less distinctive. Differences persist within categories 4 (direct contact via e-mail and mailing lists)

10. For this purpose, the companies in the sample were assigned to one of two industry groups: (1) production and retail and (2) services and telecommunications. There are no interesting differences between the two subgroups. 
and 5 (video or audio recordings of meetings and online participation in meetings). ${ }^{11}$ No industry effect was found.

In general, in the Euronext zone the Internet is an important tool in investor relations, though it is not fully exploited for this purpose yet. Much financial information is placed on the Internet, but this is in many cases a duplicate of the paper-based report. Specific advantages of the Internet, such as the use of hyperlinks for navigation and sophisticated formats, are not often exploited. Furthermore, the extent of direct communication with investors can be expanded too. Technically it is possible to participate online in meetings, but this form of communication is rarely offered on the homepages.

This study describes three stages of investor relations activities on the Internet. A few years ago, many Continental European companies were either at the end of the first stage or at the beginning of the second. This study shows that many companies in the Euronext zone are now situated in the middle or at the end of the second stage, and they are ready to move into the third stage. French and Dutch listed companies seem to move into the third stage faster than Belgian listed companies. In the third stage, the homepage includes all kinds of multimedia features, like sound, video and possibilities for online participation in meetings. In the third stage, investor relations is about creating long-term interactive relationships centered around the homepage of the company.

11. This comparison was made between 39 Dutch companies (average market capitalization: 2,816 million euros; standard deviation: 3,435 million euros) and 48 Belgian companies (average market capitalization: 2,412 million euros; standard deviation: 3,524 million euros) of equal size. A second omparison is made between French and Dutch companies of roughly equal size. Twenty Dutch companies (average market capitalization: 14,289 million euros; standard deviation: 12,301 million euros) were compared with 42 French companies (average market capitalization: 13,754 million euros; standard deviation: 9,405 million euros). Here differences between the two subgroups were relatively small. 
The globalization of capital markets will force companies to compete for capital on a larger scale. To accomplish this, companies are likely to strengthen their investor relations policies. On the offensive side, they need to intensify their investor relations activities to attract potential investors in new geographical areas. On the defensive side, they need to intensify their relations with existing investors, because foreign competitors are likely to enter their home markets in their search for capital. Given the need to enhance investor relations activities, probably more companies will enter the third stage of Internet investor relations in the near future. 


\section{REFERENCES}

Beursplein 5, (2001) 'Wij kunnen de belegger recht in de ogen kijken' [We can look investors straight in the eye], 51/52: 10-11.

Brennan, N. and S. Kelly (2000) 'Use of the Internet by Irish companies for investor relations purposes', Accountancy Ireland, 32(4): 23-25.

Craven, B.M. and C.L. Marston (1999) 'Financial reporting on the Internet by leading UK companies', The European Accounting Review, 8(2): 321-333.

Deller, D., Stubenrath, M. and C. Weber (1999) 'A survey on the use of the Internet for investor relations in the USA, the UK and Germany', The European Accounting Review, 8(2): 351-364.

Ettredge, M., Richardson, V.J. and S. Scholz (2001) 'The presentation of financial information at corporate Web sites', International Journal of Accounting Information Systems, pp. 149-168.

Gowthorpe, C. and O. Amat (1999) 'External reporting of accounting and financial information via the Internet in Spain', The European Accounting Review, 8(2): 365-371.

Hedlin, P. (1999) 'The Internet as a vehicle for investor relations: the Swedish case', The European Accounting Review, 8(2): 373-381.

Lymer, A., Debrenceny, R., Gray, G.L. and A. Rahmar (1999) 'Business reporting on the internet', Discussion paper, (November), IASC, London.

Lymer, A. and A. Tallberg (1997) Corporate reporting and the Internet - a survey and commentary on the use of the $W W W$ in corporate reporting in the UK and Finland, Paper presented at the 20th Annual Congress of the European Accounting Association in Graz, Austria.

Marston, C. (1996) 'The organization of the investor relations function by large UK quoted companies', Omega, 24(4): 477-488. 
Petravick, S. and J. Gillett (1996) 'Financial reporting on the World Wide Web', Management Accounting, 7: 26-29.

Pirchegger, B. and A. Wagenhofer (1999) 'Financial information on the Internet: a survey of the homepages of Austrian companies', The European Accounting Review, 8(2): 383-395.

Weber, S. (1985) Basic Content Analysis, Sage Publications, Beverly Hills. 
APPENDIX A: AN OVERVIEW OF PREVIOUS RESEARCH

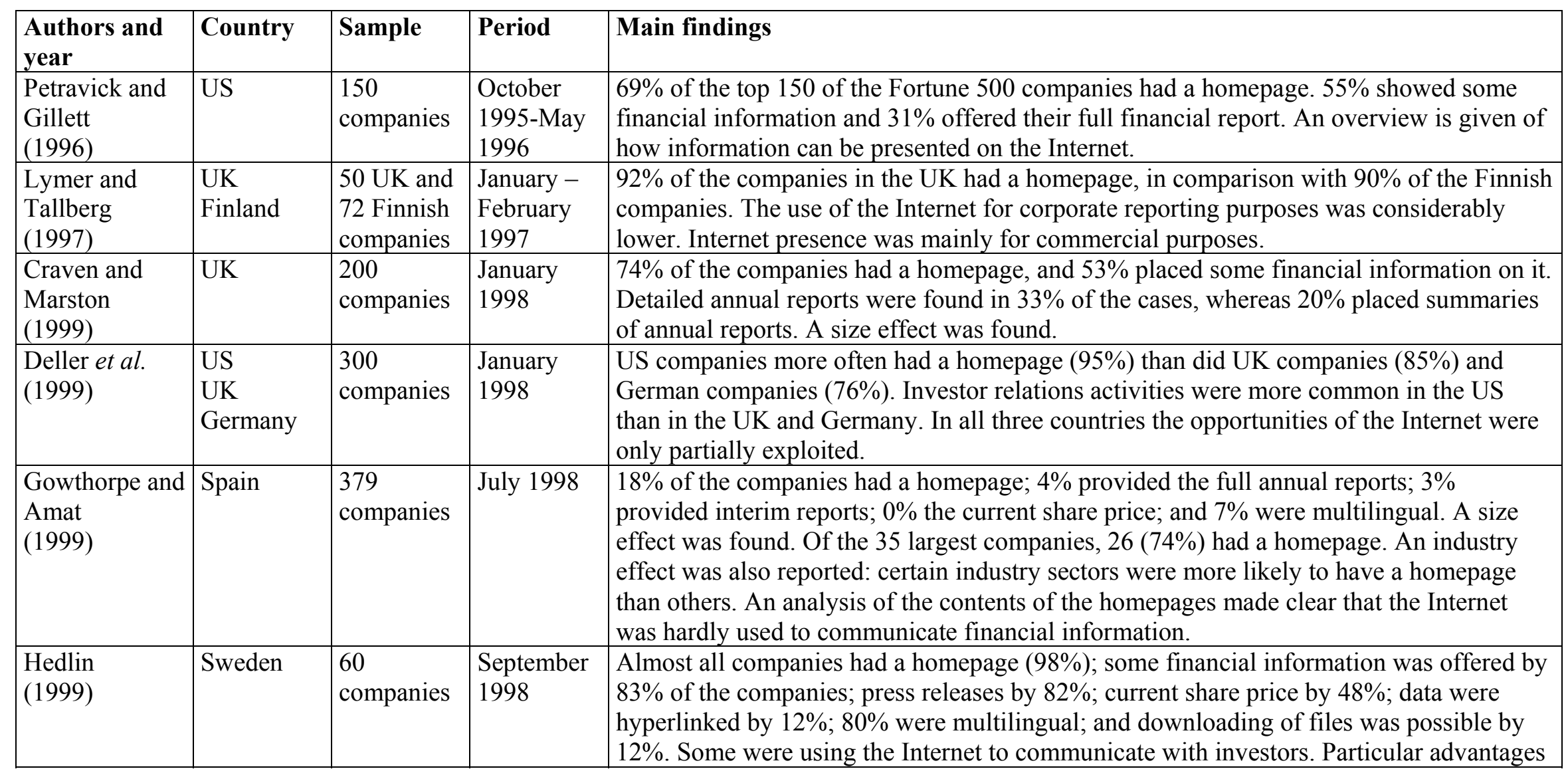




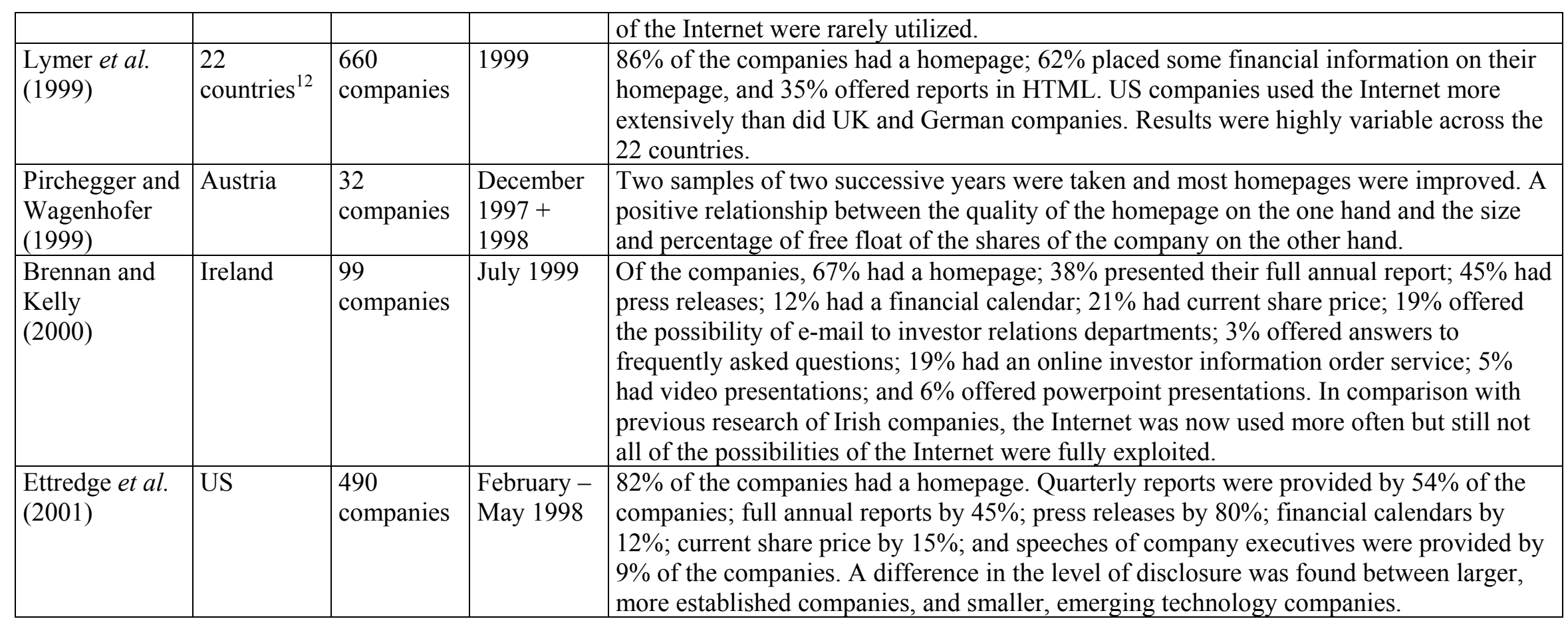

12. These include Australia, Brazil, Canada, Chile, Denmark, France, Germany, Hong Kong, Italy, Japan, Malaysia, Mexico, the Netherlands, New Zealand, Norway, Singapore, South Africa, South Korea, Spain, Sweden, the UK and the US. 
APPENDIX B: THE SAMPLE OF COMPANIES

Market Capitalization in $€$ million (as on August, 31st, 2001)

\begin{tabular}{|c|c|c|c|c|c|c|c|c|}
\hline \multicolumn{3}{|c|}{ Belgium } & \multicolumn{3}{|c|}{ France } & \multicolumn{3}{|c|}{ The Netherlands } \\
\hline \multicolumn{2}{|c|}{ Companies } & ization & Comp & Market Ca & lization & Compar & Market C: & alization \\
\hline & 2 Dexia & 20.179 & & 2 Vivendi Universal & 65.358 & & 2 ING Group & 60.297 \\
\hline & $4 \mathrm{KBC}$ & 12.157 & & 4 Sanofi Synthelabo & 52.722 & & 4 Unilever & 37.466 \\
\hline & 5 Interbrew & 11.740 & & 5 Axa & 51.558 & & 5 Philips & 34.046 \\
\hline & 6 Almanij & 8.635 & & 6 L'Oreal & 50.434 & & 6 ABN AMRO & 28.452 \\
\hline & 9 Delhaize & 5.892 & & 9 France Telecom & 40.776 & & 9 Fortis & 15.774 \\
\hline & 10 Solvay & 5.311 & & 10 Suez Lyonnaise des Eaux & 38.200 & & 10 Akzo & 13.727 \\
\hline & 11 Agfa Gevaert & 2.100 & & 11 Orange & 35.579 & & $11 \mathrm{TPG}$ & 10.699 \\
\hline & 12 Colruyt & 1.703 & & 12 StMicroelectronics & 29.738 & & 12 Gucci & 9.441 \\
\hline & 13 GIB & 1.230 & & 13 Societe Generale & 27.908 & & 13 Elsevier & 9.373 \\
\hline & 14 Umicore & 1.104 & & $14 \mathrm{LVMH}$ & 26.185 & & $14 \mathrm{VNU}$ & 8.050 \\
\hline & 20 Telindus Group & 388 & & 20 EADS & 15.191 & & 20 Hagemeyer & 2.080 \\
\hline & 21 RTL Group & 9.736 & & 21 Credit Lyonnais & 14.863 & & 21 Buhrmann & 1.073 \\
\hline & $22 \mathrm{CNP}$ & 2.483 & & 22 Peugeot & 14.820 & & 22 Getronics & 978 \\
\hline & 23 Cobepa & 2.285 & & 23 Schneider Electric & 14.649 & & $23 \mathrm{UPC}$ & 150 \\
\hline & 24 Almancora & 1.691 & & 24 Saint-Gobain & 14.559 & & 24 KPNQwest & 237 \\
\hline & 25 Sofina & 1.689 & & 25 Air Liquide & 14.073 & & 25 Versatel & 63 \\
\hline & 26 Financière d'Obourg & 1.525 & & 26 Lafarge & 12.975 & Midkap & 26 Corus & 3.040 \\
\hline
\end{tabular}




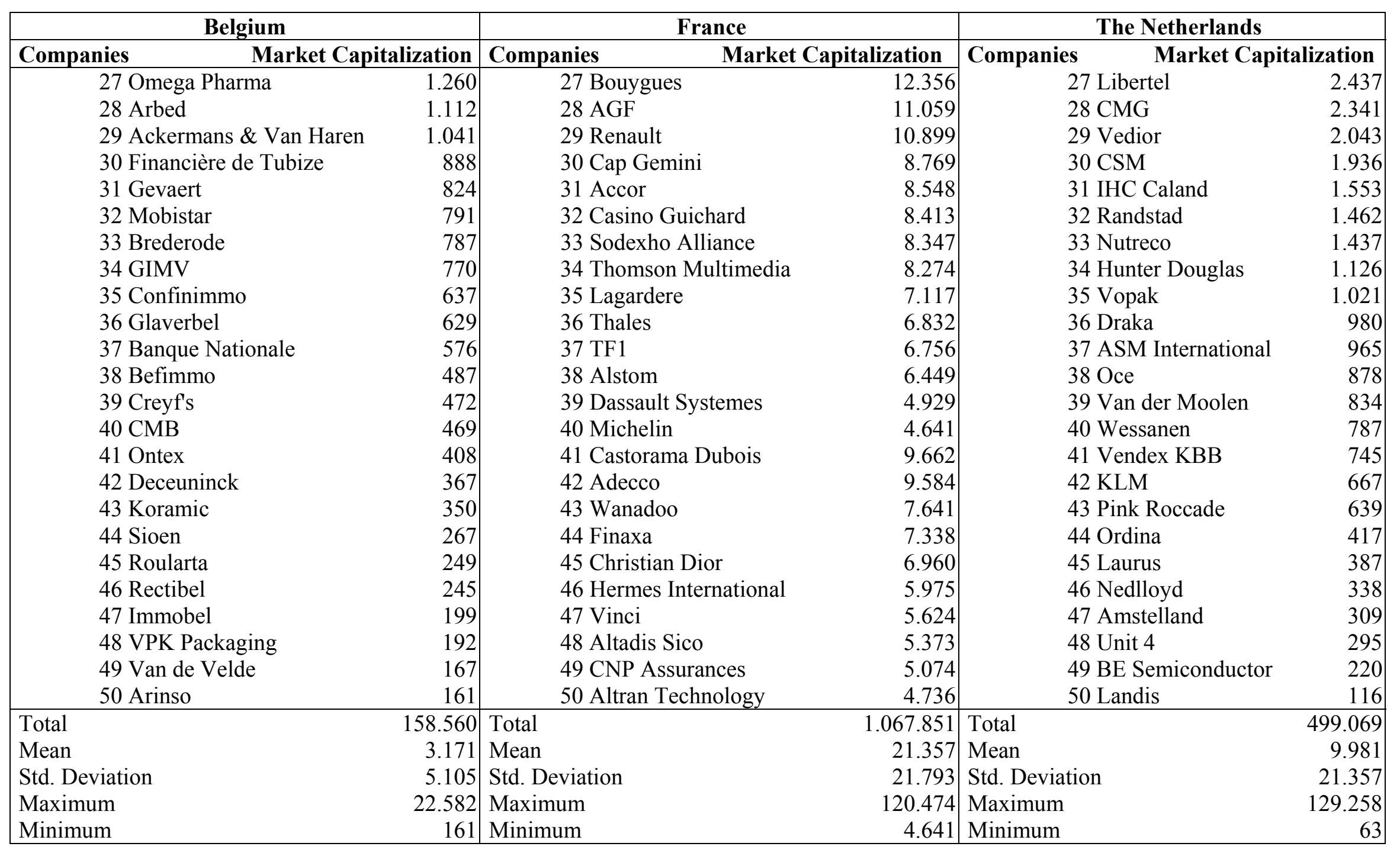


APPENDIX C: SUMMARY OF THE RESEARCH INSTRUMENT

\begin{tabular}{|c|c|c|c|}
\hline No. & Author* & Item** & Description \\
\hline \multicolumn{4}{|c|}{ Stage I: (1) Annual and interim reports on the Internet } \\
\hline 1 & DSW & Balance Sheet & No individual figures accepted \\
\hline 2 & DSW & Profit \& Loss Account & No individual figures accepted \\
\hline 3 & DSW & Notes & Comments on item number 1,2 and 4 \\
\hline 4 & DSW & Cash Flow Statement & No individual figures accepted \\
\hline 5 & DSW & Interim Reports & Six months and/or quarterly reports accepted \\
\hline 6 & GBH & Environmental and/or Social Reports & $\begin{array}{l}\text { Only a separate reports or a link. Chapter within } \\
\text { traditional reports (in PDF-file) not accepted }\end{array}$ \\
\hline 7 & GBH & Corporate Reports of Previous Years & At least two reports besides the latest report \\
\hline 8 & DSW & Financial Data Time Series & $\begin{array}{l}\text { Separate link or file to download. Within } \\
\text { traditional report (in PDF-file) not accepted }\end{array}$ \\
\hline 9 & DSW & Only Selective Accounting Data & $\begin{array}{l}\text { Any form of financial information accepted, e.g. } \\
\text { within press releases or presentations }\end{array}$ \\
\hline \multicolumn{4}{|c|}{ Stage II: (2) Press releases and further information services on the Internet } \\
\hline 10 & DSW & Press Releases & Accepted if containing financial information \\
\hline 11 & DSW & Up-to-date Investor/ Financial Calendar & $\begin{array}{l}\text { Announcements of year or quarterly results of } \\
\text { any meetings }\end{array}$ \\
\hline 12 & DSW & Current Share Price & $\begin{array}{l}\text { Share price not older than closing price of the } \\
\text { last trading day. }\end{array}$ \\
\hline 13 & GBH & Organizational Structure & $\begin{array}{l}\text { Any chart the organization accepted, e.g. } \\
\text { description of compartments or holding and } \\
\text { subsidiaries }\end{array}$ \\
\hline 14 & GBH & External Links & $\begin{array}{l}\text { Links to subsidiaries, financial or investment } \\
\text { sites }\end{array}$ \\
\hline 15 & GBH & Last Update Within $24 \mathrm{H}$ & $\begin{array}{l}\text { Mention of the latest update, press releases or } \\
\text { latest news on the homepage }\end{array}$ \\
\hline \multicolumn{4}{|c|}{ Stage III: (3) The use of presentation advantages of the Internet } \\
\hline 16 & DSW & Accounting Data Hyperlinked & Hyperlinks of components of corporate reports \\
\hline 17 & DSW & Corporate Reports in PDF-Format & Full reports or reports by chapter \\
\hline 18 & DSW & Financial Data in Processable Format & Financial data in spreadsheet or ASCII \\
\hline 19 & GBH & Corporate Reports in XBRL-Format & Reports in XBRL-language \\
\hline 20 & GBH & Multilingual & $\begin{array}{l}\text { Not only reports in more than one language, but } \\
\text { also the homepage itself }\end{array}$ \\
\hline 21 & DSW & Internal Search Engine & $\begin{array}{l}\text { Accepted if present on main page or within } \\
\text { financial part, within only the press releases not } \\
\text { accepted }\end{array}$ \\
\hline 22 & DSW & Cookies & Any kind of cookies \\
\hline \multicolumn{4}{|c|}{ Stage III: (4) Direct contact via e-mail and mailing lists } \\
\hline 23 & DSW & E-mail to Investor Relations & $\begin{array}{l}\text { Only for financial information, a general e-mail } \\
\text { to the webmaster not accepted }\end{array}$ \\
\hline 24 & DSW & Mailing List & As long as it covers financial topics \\
\hline 25 & DSW & Frequently Asked Questions & $\begin{array}{l}\text { The answers and question have to be of financial } \\
\text { nature }\end{array}$ \\
\hline 26 & DSW & Online Investor Information Order Service & $\begin{array}{l}\text { Order of reports or brochures. Acceptable if a } \\
\text { form could be filled in, sending an e-mail not } \\
\text { accepted }\end{array}$ \\
\hline \multicolumn{4}{|c|}{ Stage III: (5) Video or audio recordings of meetings and online participation in meetings } \\
\hline 27 & DSW & Online Participating in Meetings & $\begin{array}{l}\text { Any indication a participation in a meeting } \\
\text { within the near future }\end{array}$ \\
\hline 28 & DSW & Video or Audio Recordings of Meetings & Use of video or audio technology \\
\hline 29 & GBH & Presentations of Company Executives & Presentation of e.g. results or corporate strategy \\
\hline
\end{tabular}




\section{FIGURES}

Figure 1 Euronext versus Deutsche Börse and London Stock Exchange

\begin{tabular}{lc}
\hline EXCHANGE & MARKET CAPITALIZATION* \\
\hline Deutsche Börse & 4.243 \\
Euronext & 2.256 \\
London Stock Exchange & 1.947
\end{tabular}

* In $€$ million. As of December 17th, 2001. (Source: Beursplein 5, 2001) 
Figure 2 Stage I: 1 . Annual and interim reports on the Internet

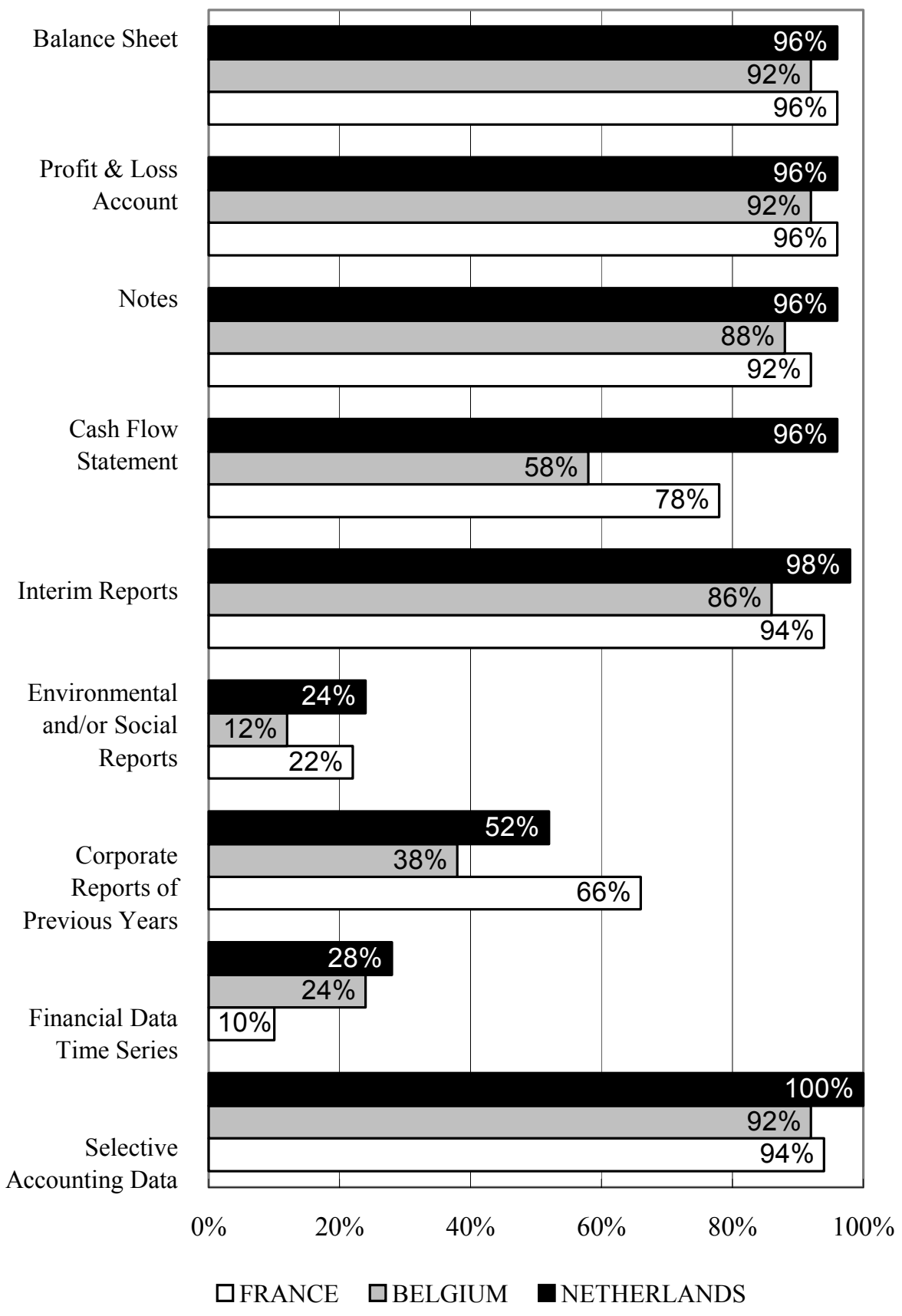


Figure 3 Stage II: 2. Press releases and further information services on the Internet

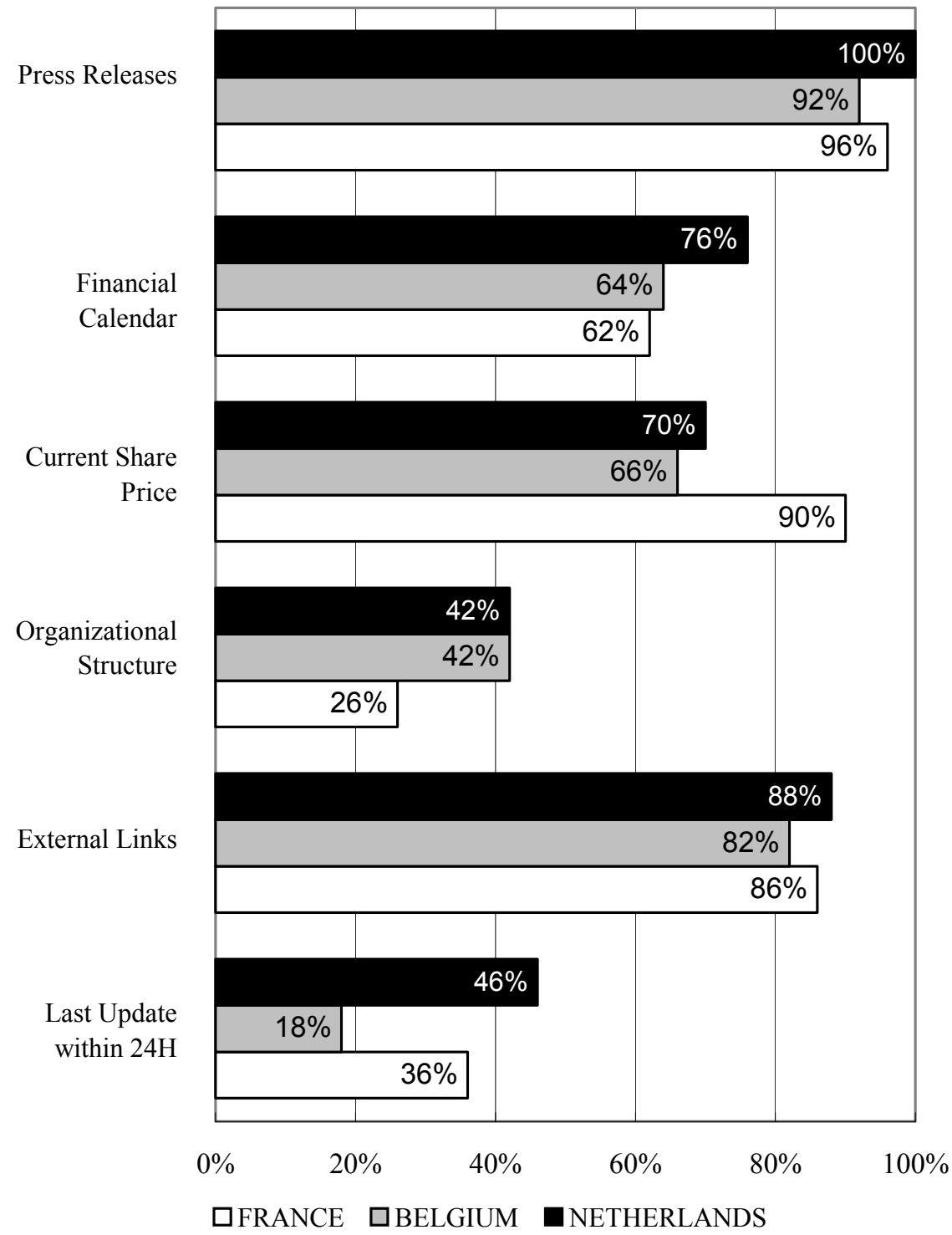


Figure 4 Stage III: 3. Presentation advantages of the Internet

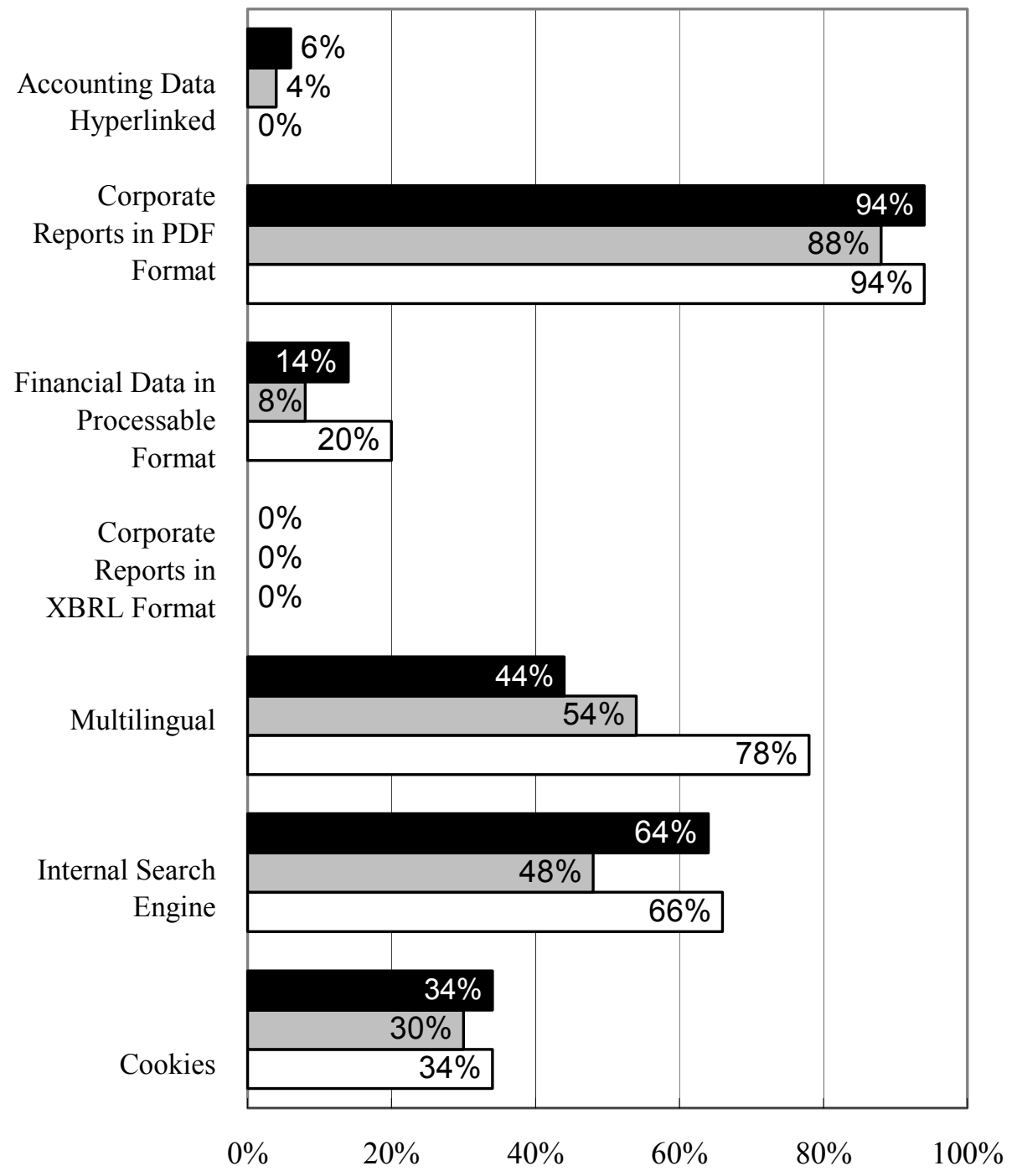

口FRANCE $\square$ BELGIUM $\square$ NETHERLANDS 
Figure 5 Stage III: 4. en 5. The use of specific communication tools

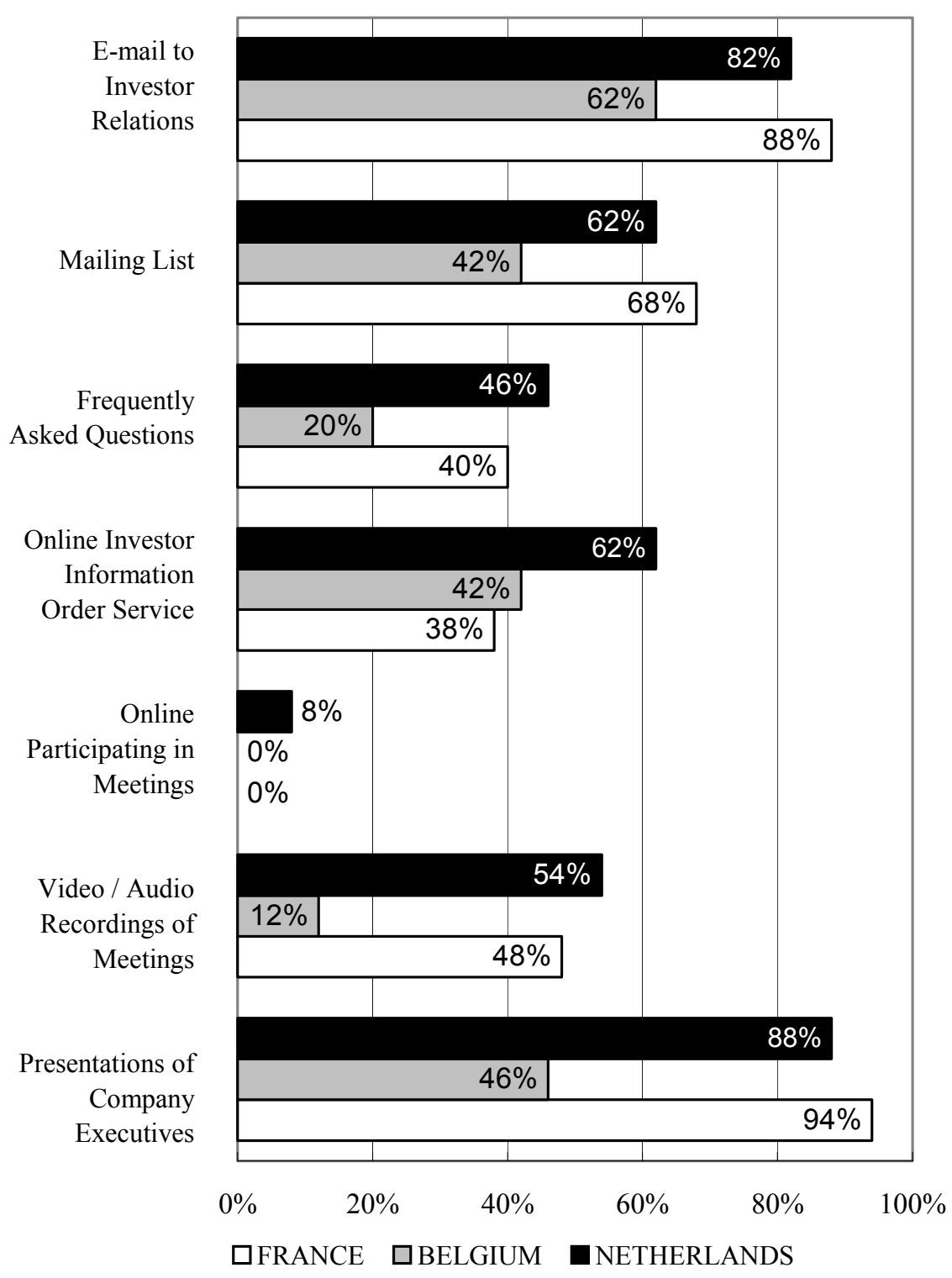


Figure 6 Size effects

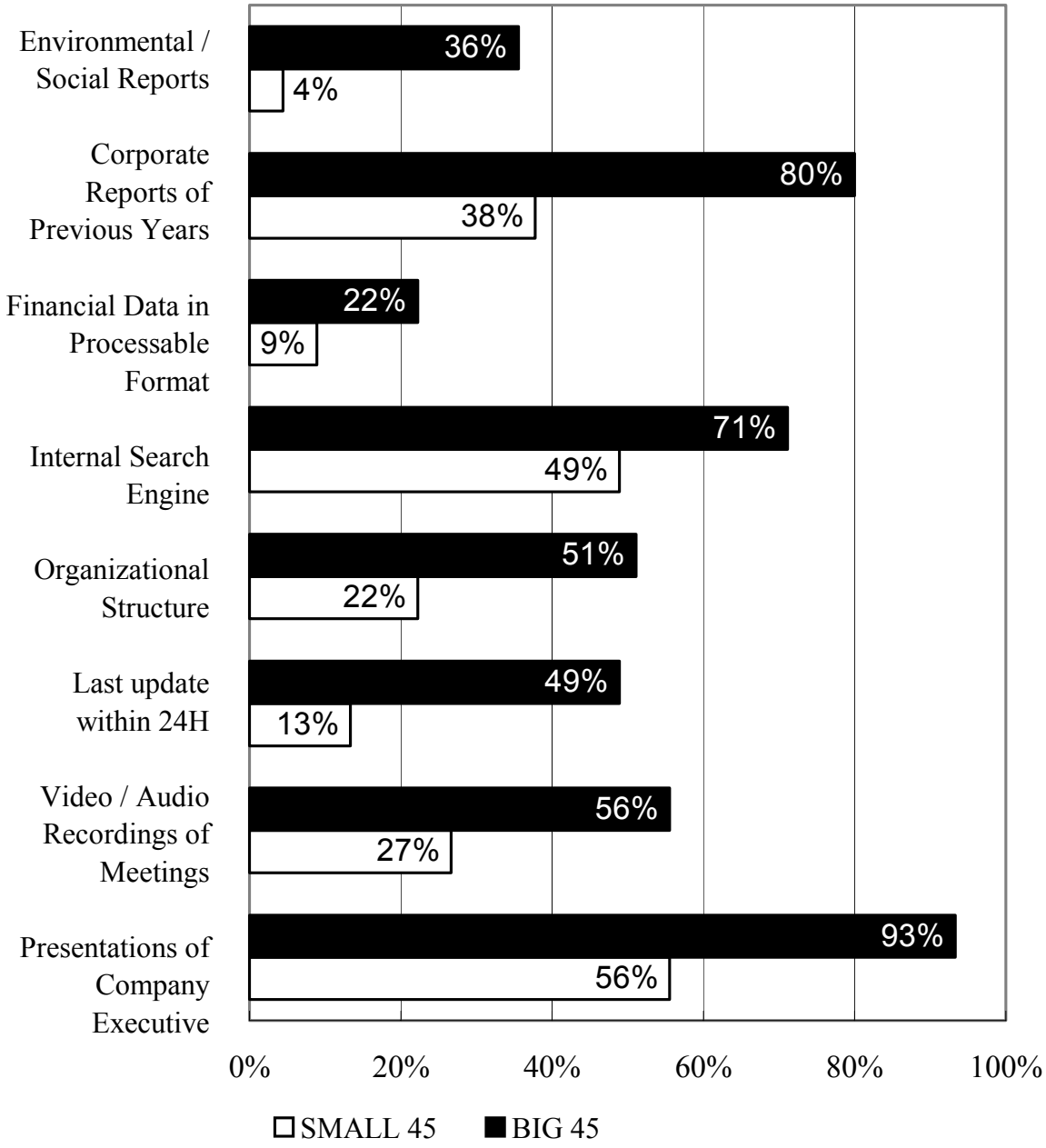

